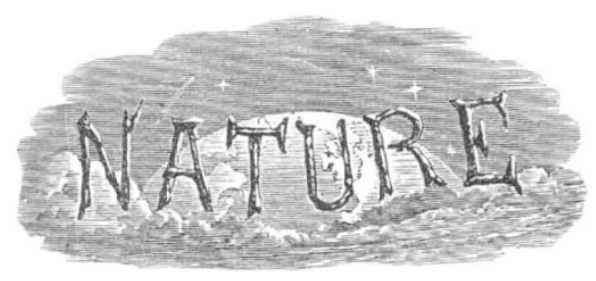

SATURDAY, MAY I4, I927.

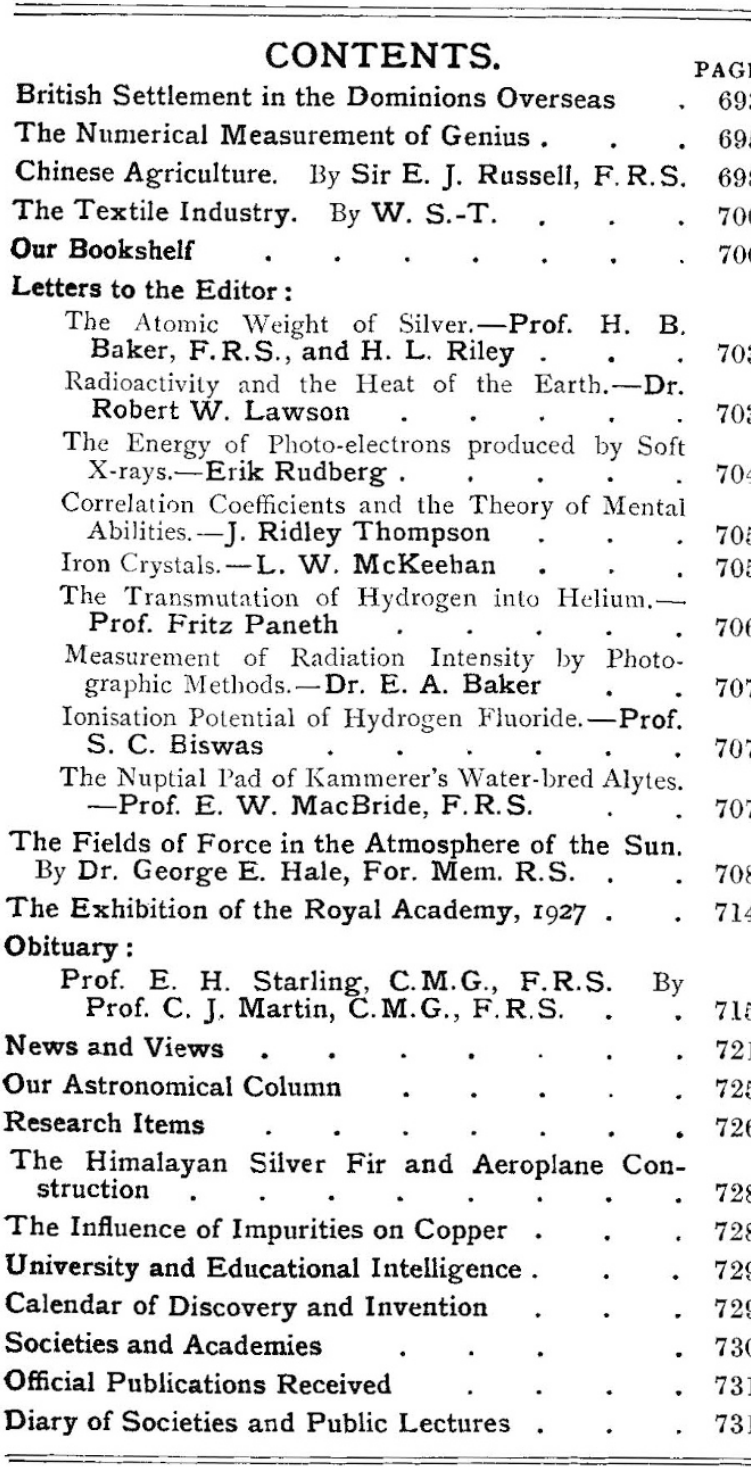

Editorial and Publishing Offices:

MACMILLAN \& CO., LTD.,

ST. MARTIN'S STREET, LONDON, W.C.2.

Editorial communications should be addressed to the Editor. Advertisements and business letters to the Publishers.

Telephone Number: GERRARD 8830.

Telegraphic Address: PHUSIS, WESTRAND, LONDON.

\section{British Settlement in the Dominions Overseas.}

TTHE various schemes which were formulated 1 just before the War to alleviate the hardships of the indigent workless and destitute and to provide for their old age had an immediate retarding effect upon emigration from the United Kingdom. The majority of emigrants are manual workers, and anything which makes for their greater security in Great Britain must increase their natural reluctance to become the sport of chance circumstance in other lands. But the empty spaces of our vast dominions must be peopled, and it is held that it is best they should be peopled by our own stock. With this object in view the Empire Settlement Act was placed on the Statute Book in 1922, to enable the Home Government, in association with the government of any part of His Majesty's Dominions, or with public authorities or public or private organisations, to formulate and co-operate in schemes for development or land settlement, and for facilitating settlement in or migration to our dominions by assistance with passages, initial allowances, training, or otherwise.

The Committee appointed to carry out these schemes has just presented to Parliament a report for 1926. ${ }^{1}$ The total number of persons assisted under the Empire Settlement Act increased from 39,559 in 1925 to 66,103 in 1926 , or rather more than two-thirds of the total number of emigrants to the Dominions and more than half the net movement of population from Great Britain. The numbers assisted to Australia and New Zealand show increases of 10,205 and 3698 ; while the numbers assisted to Canada have risen from 8809 in 1925 to 21,344 in 1926 . The Committee states that out of a net movement from Great Britain in 1926 of 115,538 persons, 93,227 went to homes within the Empire, a gratifying proportion. If this number of emigrants is maintained for the next few years, the average will be considerably above that for the decade 1901 to 1911 , when it averaged 76,000 persons a year. Yet, as the Committee points out, the net movement from Great Britain overseas represents only two-fifths of the natural increase in our home population. If it is a fact, therefore, that Great Britain is already overcrowded, and, as many think, that under our present system we cannot keep all our people who are willing to work employed, the need

1 Report of the Oversea Settlement Committee for the Year ended 31st December 1926. (Cmd. 2847.) Pp. 30. (London: H.M. Stationery Office. 1927.) $6 d$. net. 
for a greatly accelerated movement of our home population overseas is a matter of supreme urgency.

It is interesting to find that Australia absorbs more than half the migrants within the Empire. It seems reasonable that Australia should be preferred to Canada, but it is a little difficult to understand why New Zealand does not attract more settlers: it is a lovely and varied land, with a delightful climate and abundant natural resources. The Committee offers no explanation ; neither are we informed in the report why so few British migrate to South Africa : only 126 went there in 1925 and 232 in 1926 . The great increase in the number migrating to Canada is to be explained by the liberal arrangements made for their reception and settlement, including what appear to be generous terms for capital advances.

The subject of migration is important enough to warrant a much more comprehensive account of the work of the Oversea Settlement Committee than that which has been vouchsafed in this report. But the subject is dismissed in 16 pages, most of which are filled by rather vague generalisations, interspersed with quotations from other Government publications. Most of the vital statistics contained in the report are given above. A little information, it is true, is to be found in the four appendices which fill the last 11 pages of the report. Yet many aspects of the problem upon which it might be assumed members of Parliament would wish to be informed are not dealt with at all. No reference is made as to the proportion of British to other European immigrants to the Dominions, or to the assistance given by other nations to their emigrants. The tide of emigration from central and southern European States, in many of which the standard of living of the working classes is appallingly low, has an important bearing upon the overseas settlement of our own people. No attempt is made to deal with the economics of migration. If information is desired on this aspect of the subject, it must be culled from the biased and often unsubstantiated statements of overseas statesmen, or from the handbooks issued by the various shipping agencies, any of which, it must be confessed, are more informative than this official report. Yet there is much information to be gathered from an examination of our trade returns. Each family settled in Australia, for example, creates a demand for our home products the value of which is roughly equivalent to the amount required to maintain a family at home. If satisfactory arrangements could be made to transfer 20,000 families yearly to Australia, our own unemployment problem would be quickly solved.

There are other omissions. No information is given regarding the relative suitability of the various parts of the Dominions for settlement, or what are the principal crops raised or the markets they serve. Nothing is said regarding the terms on which land is granted: prospective emigrants will look in vain for information regarding the provision of the amenities of life to which they are accustomed at home, for example, education and health services, housing, transport, and communications. No indication is given of the return which can be expected from arable or mixed farming, or what are the prospects for pastoralists, based upon the purchase price of available land, the cost of domestic stock, and the cost of living.

The most serious omission, however, is in connexion with the movement of the rural populations of the Dominions towards the towns. It is well known that the urban populations of the Dominions are increasing far more rapidly than the rural populations. The percentage increase of the urban population of Australia in the decade 1911-1921 was approximately 36 , whereas the increase of the rural population in the same period was less than 9 per cent. It is a striking fact that the ratio of 'primary producers' to other classes in Australia-an agricultural country-is appreciably smaller than the corresponding ratio for Great Britain - a highly industrialised community. It is sometimes urged that our education system in Great Britain is at fault for failing to make rural life more attractive than life in our large cities: and the criticism is just. With equal justice it could be urged that Australia has not yet come to grips with the same problem. The Australian town-dwellers realise their success mainly depends upon a growing number of agriculturists, and they are prepared to support any scheme which will attract agricultural settlers from Great Britain, just as ardently as they will oppose the indiscriminate transference of our urban population to their towns ; but they fail to realise, apparently, that the flight from the land can be retarded or arrested only by complete re-orientation of their education system coupled with profound modifications of their economic policy.

It would be interesting to know from which classes of the home community overseas settlers are drawn, and it should not be difficult to include such an analysis in a report of this kind. In the summary of Lord Clarendon's report on his visit to Canada, it is stated: "Possibly somewhat too No. 3002, VoL. 119] 
strong a preference may have been shown for families with farm experience. Inexperienced families, if they have the right spirit, seem to succeed just as well as the experienced... . Families from the coal-mining districts of Great Britain appear to show as good an average of success as any other families settled under the scheme." An authoritative statement of this kind is of the utmost importance, but it would carry even greater weight if it were backed up by statistical evidence. Even such a qualitative statement, however, should do much to break down the prejudice of selection committees against offering inducements to urban workers to settle on the land in our Dominions. What the urban worker lacks in experience in comparison with the farm-worker is offset by his greater adaptability to new conditions, an adaptability born of a higher intellectual standard. Rural education in Great Britain is still in a backwater.

The Committee states that it is " conscious of the closeness of the relationship between research, development, and settlement." It would be interesting to know what kind of research the Committee has in view, what are the problems which face the Dominions for which no solution can be found on the basis of knowledge already available. Unquestionably there are vast fields of inquiry in which research workers may labour. But the Saul-like conversion of our imperial statesmen to the new faith in scientific research must not blind them, any more than the members of the Oversea Settlement Committee, to the fact that settlement and development schemes can be based upon existing knowledge. The immediate need is for a comprehensive survey of the accessible and potential resources of the Empire, an Empire stocktaking, in fact, upon which all sound schemes of overseas settlement and research should be based.

It is to be hoped that in its next report the Committee will make a real attempt to deal with the problem of re-distribution of population in a scientific spirit. There are a number of diverse contributory factors to be taken into account in an inquiry of this nature, most of which appear to have been completely ignored hitherto. The report, in fact, constitutes a slight on the members of Parliament to whom it is made. It implies either that they do not possess the intelligence to examine the problem of migration of peoples thoroughly, or that they have very little interest in a subject of vital importance to the whole of the advanced peoples of the world.

$$
\text { No. 3002, VoL. 119] }
$$

The Numerical Measurement of Genius.

Genetic Studies of Genius. Edited by Lewis M. Terman. Vol. I : Mental and Physical Traits of a Thousand Gifted Children. By Lewis M. Terman and others. Second edition. Pp. xiii +648. Vol. 2: The Early Mental Traits of Three Hundred Geniuses. By Catherine Morris Cox, assisted by Lela O. Gillan, Ruth Haines Livesay, and Lewis M. Terman. Pp. xxiii +842 . (Stanford University, Cal. : Stanford University Press ; London, Calcutta and Sydney : George G. Harrap and Co., Ltd., 1926.) $21 s$. net each vol.

T $\mathrm{T}$ is only when one studies a vast American 1 work like this - which in its first two volumes covers more than 1500 pages, with still more volumes to come-that one realises that America is not Europe, that American science, for good or bad, is obtaining an individuality of its own, and that there is some hope that a population, which anthropologically is probably the most mixed the world has ever experienced, will shake down and ultimately develop national mental, if not national physical, characteristics. America has had many difficulties to contend with; it is not usually the ablest races who emigrate, still less is it the ablest members of those races. For early emigrants also, good physique rather than strong mentality is the essential factor of success. Occasionally, as in the case of Dutch and Huguenot immigrants to England, some political or religious movement drives a better class of men to change their homeland. But the bulk of men who have colonised America, especially of recent years, are men who were not succeeding very well in Europe, and hoped to find in spacious America more room for a return for their hard labour. The very spaciousness of America has been one of its disadvantages. It was possible to acquire with relatively little effort; there was no need to preserve or to maintain past acquirements, whether mental or physical; property and tradition were of smaller value than in older and more crowded countries. There was no natural selection of physique or ability, because inferiority had merely to go farther westward, where ease of acquirement increased with every degree of longitude. The alternation from pauper to millionaire was as rapid as the reverse process, for to acquire was so simple that few learnt to conserve.

To most of us who think anthropologically, there is small wonder that America thus far has not been prolific in genius. In Vol. 2 of the work under 